\title{
19. CRACK-SEAL VEINS IN UPPER LAYER 2 IN HOLE 896A ${ }^{1}$
}

\author{
Paola Tartarotti, ${ }^{2}$ David A. Vanko, ${ }^{3}$ Gregory D. Harper, ${ }^{4}$ and Yildirim Dilek ${ }^{5}$
}

\begin{abstract}
In this paper, we present a detailed description of the morphology and microstructure of fibrous and nonfibrous veins crosscutting basaltic cores recovered from Hole 896A. The nonfibrous veins consisting of spheroidal smectite aggregates and blocky carbonate crystals indicate that minerals crystallized in open spaces during single-stage crack opening. Fibrous veins (mainly smectite + carbonate-bearing) indicate that fibers crystallized by a crack-seal mechanism, involving repeated increments of microcrack openings, followed by displacement-controlled crystal growth. We report descriptions of diagnostic features of the crack-seal veins studied. Finally, composite veins consisting of both nonfibrous and fibrous mineral infill are interpreted to result from recrystallization of fibrous minerals into blocky minerals, or to indicate a decreasing crystallization rate with respect to the fracture opening rate.
\end{abstract}

\section{INTRODUCTION}

Hole $896 \mathrm{~A}$ is located $202 \mathrm{~km}$ south of the Costa Rica Rift, the easternmost arm of the Galapagos Spreading Center (eastern equatorial Pacific). Rocks recovered from Hole 896A, which penetrates 469 meters below the seafloor (mbsf), are mainly pillow basalts and minor massive flows and breccias. One of the scientific objectives of Leg 148 in drilling Hole 896A was to examine the effects of off-axis hydrothermal activity on the basement. One of the most common manifestations of hydrothermal activity in Hole 896A is the presence of millimeter-scale veins filled by carbonate and clay minerals (mainly smectite). About 1993 veins were logged during Leg 148 in 73.68 $\mathrm{m}$ of rock, representing approximately $2 \mathrm{vol} \%$ of the recovered samples. Veins are also the most prominent structural feature observed in the cores. More than 600 veins were measured on oriented samples, and detailed structural observations were made on 30 recovered cores in order to make structural interpretations (Alt, Kinoshita, Stokking, et al., 1993).

The most important distinction between vein types in Hole 896A is the presence or absence of fibers. Fibrous veins have features pointing to their formation by the crack-seal mechanism (Ramsay, 1980 ), a process involving cycles of rock fracturing and sealing by precipitation of crystalline material. Where crack-seal fibers have not been deformed significantly after their growth, their long axis is thought to track the incremental displacement path (Durney and Ramsay, 1973), providing useful information about strain during the development of veins and larger-scale structures (Ramsay and Huber, 1983; Beutner and Diegel, 1985; Ellis, 1986). In this paper we de-

'Alt, J.C., Kinoshita, H., Stokking, L.B., and Michael, P.J. (Eds.), 1996. Proc. ODP, Sci. Results, 148: College Station, TX (Ocean Drilling Program).

${ }^{2}$ Dipartimento di Geologia, Paleontologia e Geofisica, Università di Padova, Via Giotta 1, 1-35157 Padova, Italy.tar@epidote.dmp.unipd.it

'Department of Geology, Georgia State University, Atlanta, GA 30303, U.S.A. geodav@gsusgil.gsu.edu

'Department of Geosciences, State University of New York, Albany, NY 12222, U.S.A. gdh@ jason.albany.edu

${ }^{3}$ Department of Geology and Geography, Vassar College, P.O. Box 205, Poughkeepsie, NY 12601, U.S.A. yidilek@vassar.edu scribe the morphology and microstructure of the fibrous veins, with particular emphasis on the diagnostic features of crack-seal veins.

\section{VEIN TYPES IN HOLE 896A}

The most common veins occurring in both pillow lavas and massive flows in Hole 896A comprise green clay minerals. X-ray diffraction (XRD) studies show that the clay minerals are generally trioctahedral smectite, probably saponite (Alt, Kinoshita, Stokking, et al., 1993). Calcium carbonate, commonly aragonite, is usually present in veins as a late phase following the smectite. Other vein infills are reddish $\mathrm{Fe}$-oxyhydroxides, probably made of iron oxide and/ or hydroxide mixed with clays; smectite + chalcopyrite; and saponite \pm carbonate \pm phillipsite.

Among the vein types observed at Hole 896A, nonfibrous veins consist of Fe-oxyhydroxide + brown smectite, dark- and light-green smectite, and blocky carbonate and/or smectite. Many veins filled with light-green smectite alone or associated with blocky carbonate have spheroidal ("vermicular") aggregates, evident in both hand specimen and in thin section. Fibrous veins consist of aragonite and/ or smectite. In hand specimen, carbonate fibers are easily recognizable by their silky luster (Fig. 1). Finally, composite veins consisting of both nonfibrous and fibrous mineral infill also occur.

Crosscutting and reopening relationships among veins generally indicate the following temporal sequence of secondary mineral growth in open fractures: (1) Fe-oxyhydroxide, (2) green smectite, and (3) carbonate. However, taking into account also the microstructure of the vein-filling minerals, the following general sequence of vein generations may be suggested (from oldest to youngest): (1) Feoxyhydroxide; (2) smectite with spheroidal ("vermicular") texture; (3) calcium carbonate with blocky crystal shape; (4) smectite with fibrous texture; and (5) calcium carbonate with fibrous texture. However, exceptions occur, such as smectite-bearing veins with vermicular aggregates that cut fibrous veins (e.g., Samples 148896A-26R-3, Piece 1B; 21R-2, Piece 10C; 17R-2, Piece 10; and 18R2 , Piece 1 ), and blocky carbonate-bearing veins that cut fibrous veins (e.g., Samples 148-896A-5R-3, Piece 13; and 6R-3, Piece 1). These 


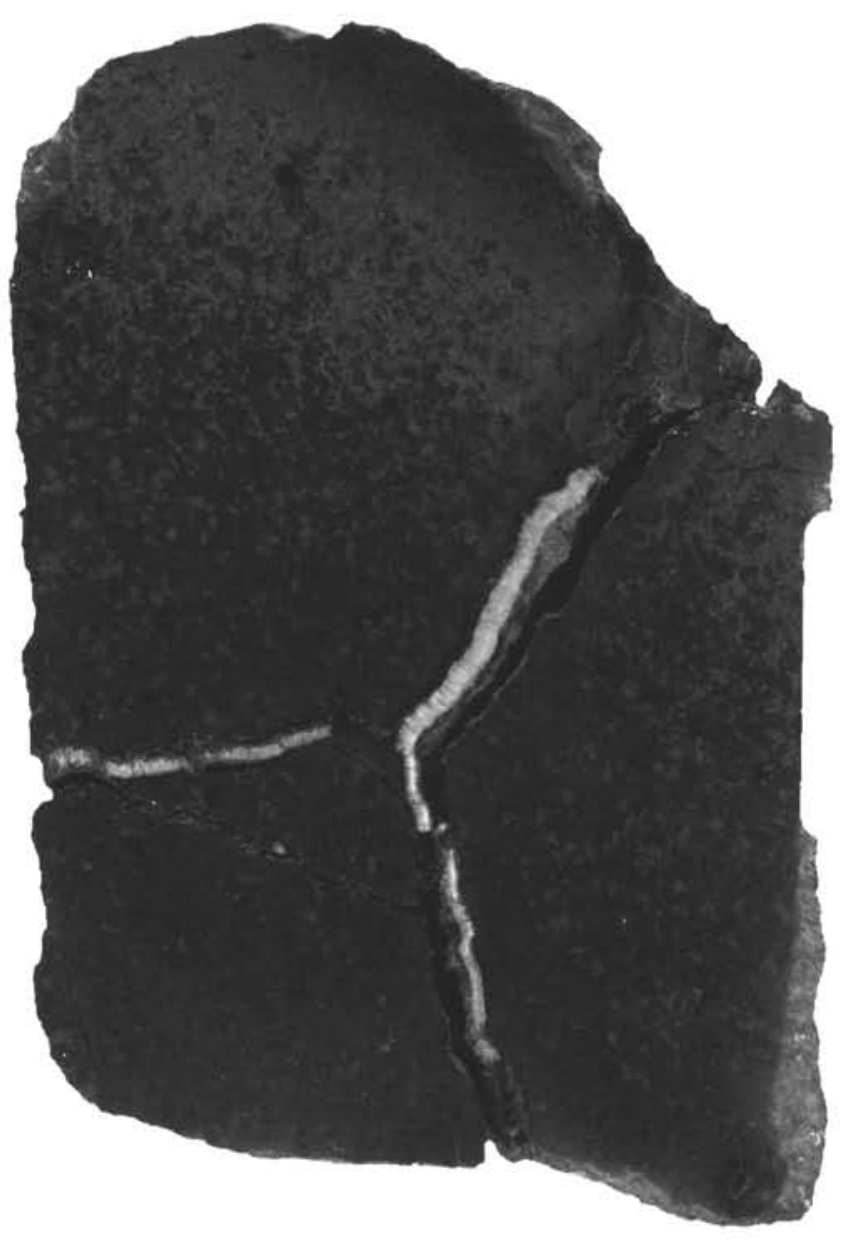

Figure 1. Hand-specimen photograph of basalt containing triple junction intersection between fibrous carbonate-filled veins. Carbonate fibers are recognizable by their typical silky luster. Piece size is about $6 \times 10 \mathrm{~cm}$ (Sample 148-896A-6R-3, Piece 4).

observations suggest that fibrous and nonfibrous veins may alternate with time.

Structural measurements carried out on cores during Leg 148 have provided data on vein orientation (mainly "true dip" data; Alt, Kinoshita, Stokking, et al., 1993; see also Harper et al., and Dilek et al., this volume, for a more comprehensive discussion on vein and fracture orientation). The histogram of true dips for all measured veins suggests that mostly steeply dipping veins are present (Alt, Kinoshita, Stokking, et al., 1993; fig. 58A). This is in contrast with the histogram of a paleomagnetically oriented subset of veins, that shows a more nearly random distribution (Alt, Kinoshita, Stokking, et al., 1993; fig. 58 B). These latter veins were reoriented with respect to azimuth using the stable paleomagnetic declination data. The stereographic projection for the reoriented data shows a strong maximum corresponding to shallow dips. The source of these apparently contrasting results is unknown, thus preventing a correct interpretation of the data. However, such a discrepancy could be related to sampling bias resulting from a vertical drill hole and to the effect of spherical geometry (Dick, Erzinger, Stokking, et al., 1992; Newmark et al., 1985) that mainly affect true dip data. True-dip histograms for (paleomagnetically unoriented) nonfibrous and fibrous veins show nonrandom distributions, with a tendency toward steeper dips and shallow dips, respectively (Alt, Kinoshita, Stokking, et al., 1993). Oriented nonfibrous veins mostly plot along a northeast-striking girdle (Alt, Kinoshita, Stokking, et al., 1993; fig. 62), but data are too

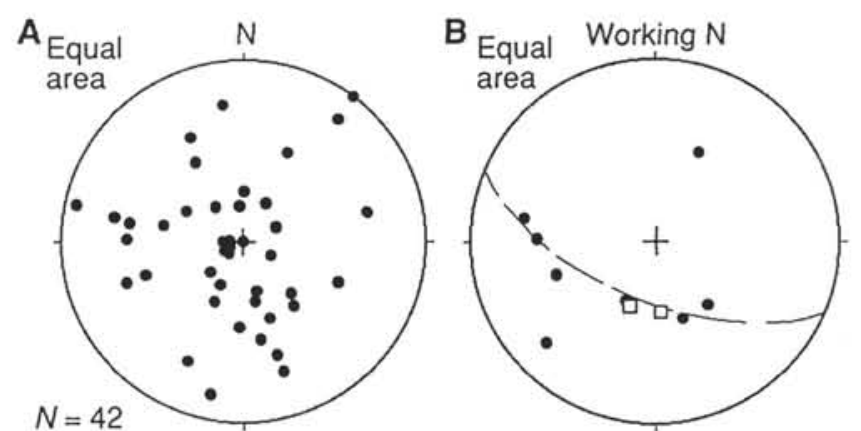

Figure 2. A. Stereographic projection of all oriented fibrous veins. B. Stereographic projection of fibrous veins from a single oriented sample (Sample 148-896A-16R-2, Piece 1). Solid circles are the poles of fibrous veins and squares represent the trend and plunge of fibers (derived from pitch measurements made with the aid of a binocular microscope). The fibers correspond closely in orientation to the pole of the corresponding veins (solid circles close to open square); i.e., the fibers are essentially normal to the vein walls (after Alt, Kinoshita, Stokking, et al., 1993).

limited for a definite interpretation. Oriented fibrous veins show considerable scatter on a stereographic projection (Fig. 2A), similar to the full set of oriented veins. However, data for individual samples may show a distribution along a girdle (Fig. 2B). The trend and plunge of fibers in veins from a single oriented sample closely correspond to the orientation of the pole of the veins (i.e., the fibers are almost normal to the vein walls; see Fig. 2B and discussion below).

\section{FIBROUS VEINS}

Fibrous veins consist of both smectite alone and smectite + calcium carbonate. Carbonate fibers alone are very rare. Fibrous veins range from $0.5 \mathrm{~mm}$ to a few millimeters in width, and are usually thinner than nonfibrous veins. Vein morphology ranges from planar to curviplanar to sinuous and irregular. These veins commonly display overlapping vein segments and triple junction intersections (Fig. $1 ; \mathrm{Pl}$. 1, Fig. 1) characteristic of fracture propagation. Vein tips in the overlapping segments mainly display a hook-shaped geometry (e.g., Samples 148-896A-7R-1, Piece 22; and 26R-2, Piece 12). Triple junctions and T-intersections are common throughout the cores (Alt, Kinoshita, Stokking, et al., 1993), but most of these veins have been observed in cores from the upper extrusive sequence. Their geometry is reminiscent of thermal contraction fractures (Pollard and Aydin, 1988). The intersecting vein arms in triple junctions may be composed of the same material having similar vein thickness (e.g., Sample 148-896A-7R-1, Piece 7). In other cases, two arms are filled with one mineral, whereas the thinner arm is composed of a different mineral (e.g., Sample 148-896A-14R-2, Piece 2B).

On the basis of thin-section observations of the recovered samples we recognize the following fibrous vein types: (1) simple fibrous veins consisting of smectite fibers alone or of smectite fibers + calcium carbonate fibers (very common); (2) composite veins consisting of both "vermicular" smectite aggregates and smectite fibers; (3) composite veins filled with smectite fibers along the vein walls and blocky calcium carbonate in the vein center (least common).

Smectite fibers have their (001) plane orthogonal to the vein wall. In monomineralic smectite veins, the fibers extend from one wall to the other, and may be straight (e.g., Sample 148-896A-26R-2, Piece 12; Pl. 1, Fig. 1; see also Pl. 2, Fig. 4) or curved (e.g., Sample 148$896 \mathrm{~A}-12 \mathrm{R}-2$, Piece 3). The long dimension of smectite fibers can be either perpendicular to the vein walls (PI. 1, Fig. 1), or, less commonly, nonperpendicular (e.g., Samples 148-896A-6R-3, Piece 1; and 14R-2, Piece 16A). In composite veins, smectite fibers fill the vein 
center and smectite with "vermicular" aggregates grow along the vein walls (Sample 148-896A-21R-2, 87-89 cm). The opposite zonation has never been observed in the samples studied. In composite veins filled with blocky calcium carbonate, smectite fibers are along the vein walls. In most veins, smectite fibers contain regularly spaced (a few microns) bands of inclusions of the wall rock ("inclusion bands"; Ramsay, 1980) which are visible only at high magnification and consist of tiny crystals regularly orientated in parallel lines (PI. 1, Fig. 2). In other cases, inclusion bands consist of millimeter-scale fragments of the wall rock that generally form irregular arrays subparallel to the vein walls (Pl. 1, Fig. 1).

Fibrous carbonate veins mostly contain calcium carbonate fibers in the vein center and smectite fibers typically along the vein walls (e.g., Sample 148-896A-2IR-1, Piece 7), but sometimes alternating with carbonate fibers (e.g., Sample 148-896A-6R-1, Piece 4; Pl. 1, Fig. 3). In this latter case, veins are commonly deformed, where fibrous carbonate fiber packets are faulted within the smectite matrix in an extended "domino-like" style (e.g., Sample 148-896A-6R-3, Piece 1; and 10R-1, Piece 8). This effect probably results from different rheological behavior of the "softer" smectite and "harder" carbonate fibers, when the vein is affected by localized microfaulting.

Carbonate fibers (mostly aragonite) are generally straight and subparallel, and are oriented with their long axis orthogonal or slightly oblique to the vein walls (e.g., Sample 148-896A-7R-1, Piece 10B; PI. 1, Fig. 4). These fibers usually show constant width (up to $50 \mu \mathrm{m}$ ) across the vein and do not exhibit euhedral terminations (comb structures) like those of crystals in nontectonic veins or cavities (Durney and Ramsay, 1973). In some samples carbonate fibers become wider from the vein walls toward the vein center at the expense of their neighbors, suggesting that the sense of crystal growth was toward the vein center (syntaxial vein; e.g., Sample 148-896A-5R-3, Piece 1A; and 7R-1, Piece 1). In other cases, fiber coarsening toward the vein walls from the vein center is observed (antitaxial vein; e.g., Sample 148-896A-21R-1, Piece 7). In the latter sample, the carbonate vein contains a line of wall-rock solid inclusions that runs along the central part of the vein ("central suture"?; Ramsay and Huber, 1983). These rock fragments are incorporated within the fibers and impart a "dirty" appearance to the crystals.

When observed under crossed polarizers, however, the carbonate fibers are optically continuous across the vein (Pl. 1, Fig. 4) and rarely show a central surface separating fibers of differing optic orientation (central suture). Fibers like those shown in Plate 1 (Fig. 4) are generally subparallel, displaying a strong shape orientation and constant width. These fibers are optically continuous across the vein but show different orientations of their optic axes. This type of fiber structure recalls that of "stretched crystals" (Durney and Ramsay, 1973; Ramsay and Huber, 1983) except for the fact that the study fibers have not developed with optical continuity on mineral grains in the wall-rock. Indeed, the walls of fibrous carbonate veins are underlined by smectite fibers.

In samples where triple junctions occur (e.g., Samples 148-896A7R-1, Piece 10B; and 7R-1, Piece 22), carbonate fibers are still oriented with their long axis orthogonal to the veins walls. In this case, fibers that fill the curved part of the triple junction are arranged in a seemingly radiating array (Pl. 2, Fig. 1).

Fibrous carbonate veins may also contain millimeter-scale blocky or elongated carbonate crystals that show no clear textural relations with the fibers. The blocky crystals are commonly arranged in a mosaic-like texture (e.g., Samples 148-896A-2R-1, Piece 17, Pl. 2, Fig. 2; and 21R-1, Piece 7). In Sample 148-896A-5R-2 (Piece 1B), a composite vein about $8 \mathrm{~mm}$ wide is filled with fibrous smectite + calcium carbonate and blocky carbonate crystal, showing a clear textural zonation with fibers at the vein walls and blocky crystals at the vein center. The presence of both types of crystals in the vein we studied may be interpreted as vein reopening (see discussion below) or, as recrystallization of fibrous into blocky crystals. This latter explanation seems to be more likely for Sample 148-896A-2R-1 (Piece 17) and Sample 148-896A-21R-1 (Piece 7), where distribution of fibrous and blocky crystals appears quite irregular. This interpretation is also supported by optical cathodoluminescence $(\mathrm{CL})$ images of composite carbonate veins (Pl. 2, Fig. 3) which show the occurrence of two generations of carbonate crystals (that luminesce with different brightness) that are irregularly distributed through the vein. The bright crystals (calcite) have irregular grain boundaries and replace the dull crystals (aragonite). The occurrence of both aragonite and calcite in other recovered samples has been confirmed by XRD results (Alt, Kinoshita, Stokking, et al., 1993, table 4) and by cathodoluminescence images (Table 1). In a few veins we studied, although XRD data suggest the presence of one carbonate type, cathodoluminescence images reveal two generations of carbonate (Table 1). In Sample 148-896A-15R-1 (Piece 15), a fibrous vein is filled with all aragonite fibers except for one lonely calcite fiber that is recognizable for its bright CL color. This occurrence may be interpreted as an example of incipient recrystallization of aragonite into calcite.

\section{Fluid Inclusions}

Fibrous and blocky aragonite crystals filling the veins we studied commonly contain fluid inclusions that are irregularly distributed. The inclusions are usually lens-shaped and occur along sub-planar arrays indicating that they were trapped during fracture healing in the presence of fluid (i.e., all are secondary inclusions). In fibrous veins, the inclusion arrays usually cut intercrystalline boundaries, indicating that fibers were fractured as a multicrystalline unit. Only rarely, these inclusion arrays are subparallel to the vein walls and perpendicular to the fibers. In general, however, there is no preferred orientation of healed fractures. Consequently, the fluid inclusions arrays do not unequivocally represent entrapment of the fluid from which the aragonite initially grew by crack-seal.

Typical inclusions measure from 2 to $10 \mu \mathrm{m}$ in diameter, and contain a single-phase, aqueous liquid, suggesting that the temperature of trapping was $<50^{\circ} \mathrm{C}$ (Goldstein and Reynolds, 1994). Nineteen inclusions in three samples were studied in detail to investigate their composition. Because ice melting temperatures must be determined in the presence of a vapor phase, and because the natural fluid inclusions are single-phase, a vapor phase was induced by deliberately over-

Table 1. XRD results and cathodoluminescence observations from some carbonate veins in samples from Hole 896A.

\begin{tabular}{|c|c|c|c|}
\hline $\begin{array}{l}\text { Core, } \\
\text { section }\end{array}$ & Piece & XRD & Cathodoluminescence \\
\hline $2 R-1$ & 17 & Aragonite & Fibrous part dull: blocky part dull \\
\hline $5 \mathrm{R}-2$ & IB & Aragonite & Blocky, dull CL \\
\hline $6 \mathrm{R}-2$ & $11 \mathrm{~A}$ & Aragonite & Blocky, dull zoned $C L$; very few bright-CL interstitial grains \\
\hline $15 \mathrm{R}-1$ & 15 & Aragonite & Dull fibrous, with one single very intensely bright-CL fiber (calcite) \\
\hline $2 \mid R-1$ & 7 & Calcite & Fibrous, intense bright $\mathrm{CL}$ \\
\hline $23 R-1$ & 11 & Calcite & Fibrous, intense bright $\mathrm{CL}$, variable in bands \\
\hline $23 \mathrm{R}-2$ & $4 \mathrm{~A}$ & ? & Fibrous bright $\mathrm{CL}$, calcite? \\
\hline $24 \mathrm{R}-5$ & $3 \mathrm{~A}$ & Calcite & Fibrous bright $\mathrm{CL}$, blocky dull CL \\
\hline
\end{tabular}

Note: $\mathrm{CL}=$ cathodoluminescence. 
heating the samples on a heating and freezing $(\mathrm{H} / \mathrm{F})$ stage (a temperature between $250^{\circ}$ and $275^{\circ} \mathrm{C}$ was found to be sufficient). This procedure stretched the inclusions and, after cooling to room temperature, the inclusions contained liquid plus vapor. Subsequently, measurements of the stable melting temperature of ice $\left[\mathrm{T}_{\mathrm{m}}\right.$ (ice) $]$ ranged between $-1.8^{\circ} \mathrm{C}$ and $-2.3^{\circ} \mathrm{C}$ with an average $\mathrm{T}_{\mathrm{m}}$ (ice) of $-2.0^{\circ} \mathrm{C}$. The corresponding salinity, expressed as equivalent weight percent $\mathrm{NaCl}$ (wt\% $\mathrm{NaCl}$ equivalent), was determined using published vapor-saturated freezing point depressions. The resulting values of $\mathrm{NaCl}$ equivalent (in wt \%) range from 3.87 to 3.06 with an average $3.5 \mathrm{wt} \% \mathrm{NaCl}$ equivalent. The average $T_{m}$ (ice) for the fluid inclusions (Fig. 3) nearly matches that of seawater $\left[\mathrm{T}_{\mathrm{m}}(\right.$ ice $)=-2.1^{\circ} \mathrm{C}$, corresponding to 3.5 $\mathrm{wt} \% \mathrm{NaCl}$ equivalent, for seawater]. The observed range in fluid inclusion salinities is $\pm 14 \%$ relative to seawater, that is significantly less than the range observed in modern hot spring fluids, which can vary between about 0.4 and $7 \mathrm{wt} \% \mathrm{NaCl}$ equivalent (from $70 \%$ below to $200 \%$ above seawater concentration) (Von Damm and Bischoff, 1987; Von Damm, 1988; Bowers et al., 1988; Butterfield et al., 1990). Apparently, there is no evidence in Hole 896A samples for extreme fluid salinity variations, and hence no reason to invoke hydrothermal processes such as phase separation.

\section{DISCUSSION}

Microstructural arrangement of the vein-filling minerals provides information about the vein formation and evolution. Veins filled with vermicular smectite aggregates and/or blocky carbonate may be interpreted as fractures filled by minerals crystallizing in open space. In this case, crystal growth occurred in fluid-filled spaces during singlestage opening, and was not controlled by incremental dilations in the vein, thus providing vuglike or irregular textures (Durney and Ram-

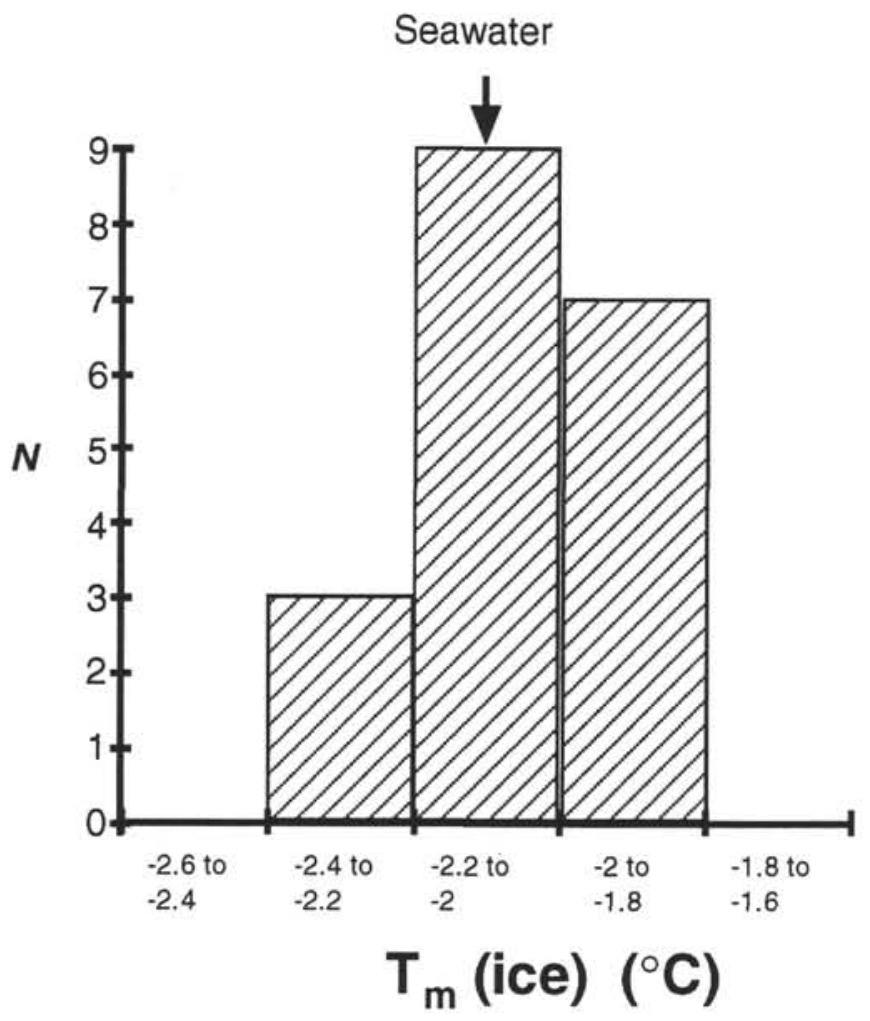

Figure 3. Ice melting temperatures of fluid inclusions from carbonate veins. say, 1973). In contrast, fibrous veins have features pointing to a cyclic crystal growth controlled by incremental vein dilations (i.e., the crack-seal mechanism), consisting of repeated increments of microcrack opening, followed by sealing due to precipitation of material from solution (Ramsay, 1980). In this case, crystal growth is displacement-controlled, thus providing fibrous textures. The crack-seal mechanism is a form of rock recracking and hence indicates that effective stress magnitudes change in time (Engelder, 1987). The nature of effective stress cycling is not known with certainty but changes in fluid pressure along fractures is considered as one mechanism causing significant effective stress changes in rock (Engelder, 1987) Cycling of the fluid pressure can result in cyclic changes in effective stress which repeatedly exceeds the tensile strength of the vein material or vein-host rock boundary.

Diagnostic features in crack-seal veins comprise (1) the strong shape orientation of crystals; (2) the occurrence of regularly spaced lines of solid inclusions parallel to the vein walls (inclusion bands); and (3) the presence of fluid inclusions along sub-planar arrays. Moreover, a common feature of crystal fibers filling syntectonic veins is the poor degree of preferred orientation of their optic axes (Durney and Ramsay, 1973). All these features are observed in the study fibrous veins.

The crystal shape and the sense of progressive crystal growth, as inferred from change in fiber width, suggest that the veins studied are either syntaxial (fiber coarsening towards the vein center), or antitaxial (fiber coarsening towards the vein edges, inclusion bands within the crystals). However, the "median suture" typically described in syntaxial and antitaxial veins is commonly poorly defined in the study samples and is represented by a more or less centrally located line of "dusty" included rock fragments.

It is commonly accepted that fiber long axes track the incremental displacement path during fiber growth (Durney and Ramsay, 1973; Ramsay and Huber, 1983; Beutner and Diegel, 1985; Ellis, 1986), although some authors have demonstrated that this is not always the case (Cox, 1987; Urai et al., 1991). Syntectonic straight fibers (either orthogonal or oblique to the vein wall) have their long axes parallel to the direction of maximum incremental longitudinal strain. Curved fibers likely correspond to the changes in orientation of the principal strain increments, although this relation is not always simply detectable (Ramsay and Huber, 1983). The arrangement of vein-filling fibers from Hole 896A suggests that veins can be interpreted as filled extension fissures with fibers growing in the direction of extension. The dilation that has taken place during the vein formation can be inferred from the fibers linking points that were once in contact (Pl. 2, Fig. 4). The displacement vector in the veins studied was either orthogonal, as confirmed by the trend and plunge of fibers measured in oriented veins (Alt, Kinoshita, Stokking, et al., 1993), or oblique to the vein walls. Accordingly, fiber long axes orientation in triple junction-veins suggest extension and hence volume expansion in all directions (Alt, Kinoshita, Stokking, et al., 1993).

Solid inclusion bands of wall-derived material are particularly abundant in the smectite fibrous veins, both in monomineralic and in composite smectite + carbonate veins. The inclusion arrangement in bands parallel to the vein walls appears to mark successive opening along the vein-wall contact with progressive evolution of the vein.

The distribution of fluid inclusions in veins is generally irregular. However, the occurrence, although scarce, of subplanar arrays parallel the vein walls in some aragonite fibrous veins can be considered as a diagnostic feature of "inclusion bands" that were trapped during crack-seal. They cut intercrystalline boundaries of fibers, suggesting multiple fracture opening and healing in the presence of a fluid.

Composite veins consisting of both smectite + carbonate fibers and blocky carbonate crystals may be variously interpreted. We suggest that in cases where textural relations between fibers and blocky crystals are irregular and poorly defined, then recrystallization of blocky crystals upon fibers probably occurred. In contrast, where fi- 


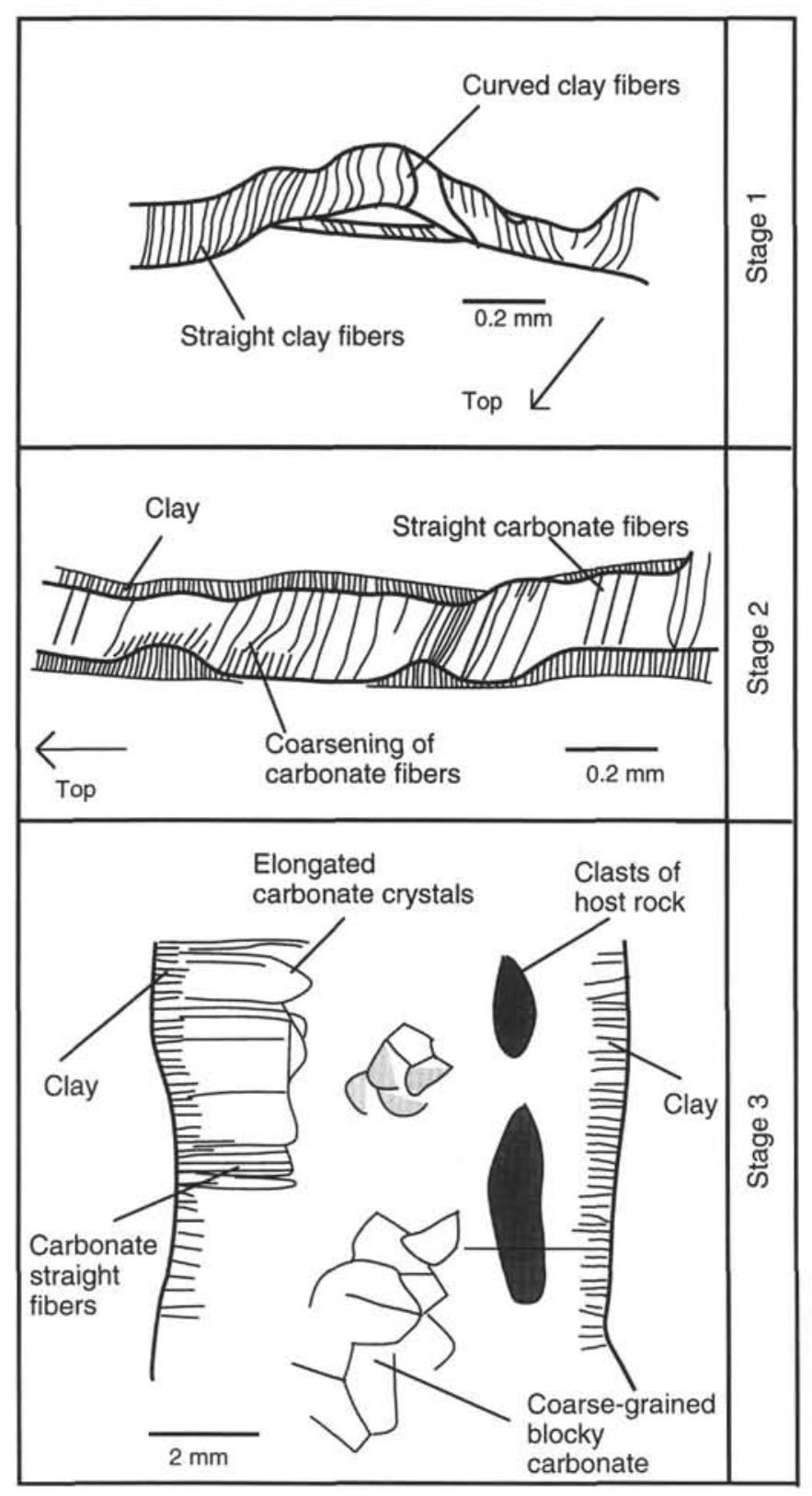

Figure 4. Illustration of the evolution of three main types of veins in sequential order as a result of crack-seal mechanism (modified after Alt, Kinoshita, Stokking, et al., 1993). Stage 1: Formation of monomineralic fibrous veins filled with clay (mainly smectite). Clay fibers may be straight or curved (from Sample 148-896A1R-1, Piece 11).The up direction (top) of the rock piece on the vertical axis is shown. Stage 2: Reopening of the clay-filled vein and subsequent filling with straight carbonate fibers. Carbonate fibers may show constant width across the vein or become wider toward the vein center (from Sample148-896A-3R-1, Piece 17). The up direction of the rock piece on the vertical axis is shown. Stage 3: Composite vein filled with fibrous clay + carbonate along the vein walls, and blocky carbonate in the center (from Sample 148-896A-6R-3, Piece 1). This zoned pattern may be explained by multiple opening episodes along with decreasing of crystallization rate with respect to opening rate (see text for discussion). bers and blocky crystal display a zoning pattern, multiple opening stages likely occurred. A schematic evolution of fibrous veins into composite veins is illustrated in Figure 4. During stage 1, monomineralic fibrous veins are formed by crack-seal mechanism. Reopening and vein-filling by circulating fluid are responsible for compound fibrous veins (stage 2). Stage 3 illustrates further opening of the fibrous veins followed by filling (or recrystallization) with coarse-grained, blocky crystal.

Similar zoning patterns have been described in carbonate veins from the Helvetic nappes (Dietrich and Grant, 1985). It has been inferred that during the development of these latter veins, the rate of crystallization could no longer keep up with the rate of opening, so that one side of the fibrous vein was occupied by blocky crystals. Experimental studies (in progress) on carbonate fibers growth in absence of deformation seem to suggest that the type of crystal (i.e., whether fibers or blocky) depends on the growth conditions such as the level of supersaturation of the fluid (T. Li, pers. comm., 1994).

\section{SUMMARY AND CONCLUSIONS}

The basaltic samples of Hole 896A recovered during Leg 148 are characterized by two main vein types: nonfibrous and fibrous veins. Crosscutting relations between veins suggest that the two vein types may alternate with time. Nonfibrous veins are thought to represent fractures filled by minerals crystallizing in open cavities where fluidfilled spaces were available for crystal growth. Fibrous veins are interpreted as crack-seal veins during which narrow cracks propagate followed by the filling of the open space with a cement. Individual growth increments in these veins may be on the order of a few micrometers wide, as suggested by the spacing of inclusion bands in smectite veins, whereas the entire vein may be several $\mathrm{mm}$ wide. Crystal growth in these crack-seal veins is displacement controlled, and the fiber long axes generally believed to be parallel to the displacement direction. Interestingly, complex fibrous veins with triple junctions show that extension occurred in virtually all directions. Composite veins consisting of fibrous and nonfibrous mineral infill is interpreted as a result of recrystallization processes (e.g., blocky carbonate from carbonate fibers) or, alternatively, as a result of a decreasing crystallization rate with respect to the opening rate during crack-seal process.

\section{ACKNOWLEDGMENTS}

We thank G. Mitra and S.F. Cox for their comments on the paper. We also thank Taohong $\mathrm{Li}$ of the Department of Geosciences of Albany, N.Y., for the helpful discussion, and G.B. Rhodes of the Department of Geology of the Georgia State University for her contribution on fluid inclusions study. Financial support was in part provided by the Italian Council of National Research, C.N.R., to P. Tartarotti.

\section{REFERENCES}

Alt, J.C., Kinoshita, H., Stokking, L.B., et al., 1993. Proc. ODP, Init. Repts., 148: College Station, TX (Ocean Drilling Program).

Beutner, E.C., and Diegel, F.A., 1985. Determination of fold kinematics from syntectonic fibers in pressure shadows, Martinsburg Slate, New Jersey. Am. J. Sci., 285:16-50.

Bowers, T.S., Campbell, A.C., Measures, C.I., Spivack, A.J., Khadem, M. and Edmond, J.M., 1988. Chemical controls on the composition of vent fluids at $13^{\circ}-11^{\circ} \mathrm{N}$ and $21^{\circ} \mathrm{N}$, East Pacific Rise. J. Geophys. Res., 93:4522-4536.

Butterfield, D.A., Massoth, G.J., McDuff, R.E., Lupton, J.E., and Lilley, M.D., 1990. Geochemistry of hydrothermal fluids from Axial Seamount Hydrothermal Emissions Study vent field, Juan de Fuca Ridge: subsea- 
floor boiling and subsequent fluid-rock interaction. J. Geophys. Res., 95:12895-12921.

Cox, S.F., 1987. Antitaxial crack-seal vein microstructures and their relationship to displacement paths. J. Struct. Geol., 9:779-787.

Dick, H.J.B., Erzinger, J., Stokking, L.B., et al., 1992. Proc. ODP, Init. Repts., 140: College Station, TX (Ocean Drilling Program).

Dietrich, D., and Grant, P.R., 1985. Cathodoluminescence petrography of syntectonic quartz fibres. J. Struct. Geol., 7:541-553.

Durney, D.W., and Ramsay, J.G., 1973. Incremental strains measured by syntectonic crystal growth. In De Jong, K.A., and Scholten, R. (Eds.), Gravity and Tectonics: New York (Wiley), 67-96.

Ellis, M.A., 1986. The determination of progressive deformation histories from antitaxial syntectonic crystal fibres. J. Struct. Geol., 8:701-709.

Engelder, T., 1987. Joints and shear fractures in rock. In Atkinson, B.K. (Ed.), Fracture Mechanics of Rock: London (Acad. Press), 27-69.

Goldstein, R.H., and Reynolds, T.J., 1994. Systematics of Fluid Inclusions in Diagenetic Minerals. SEPM Short Course 31: Tulsa, OK (Soc. Econ. Paleontol. Mineral.).

Newmark, R.L., Anderson, R.N., Moos, D., and Zoback, M.D., 1985. Sonic and ultrasonic logging of Hole 504B and its implications for the structure, porosity, and stress regime of the upper $1 \mathrm{~km}$ of the oceanic crust. In
Anderson, R.N., Honnorez, J., Becker, K., et al., Init. Repts. DSDP, 83: Washington (U.S. Govt. Printing Office), 479-510.

Pollard, D.D., and Aydin, A., 1988. Progress in understanding jointing over the past century. Geol. Soc. Am. Bull., 100:1181-1204.

Ramsay, J.G., 1980. The crack-seal mechanism of rock deformation. Nature, 284:135-139.

Ramsay, J.G., and Huber, M.I., 1983. The Techniques of Modern Structural Geology (Vol. 1): Strain Analysis: London (Acad. Press).

Urai, J.L., Williams, P.F., and van Roermund, H.L.M., 1991. Kinematics of crystal growth in syntectonic fibrous veins. J. Struct. Geol., 13:823-836.

Von Damm, K.L., 1988. Systematics of and postulated controls on submarine hydrothermal solution chemistry. J. Geophys. Res., 93:4551-4561.

Von Damm, K.L., and Bischoff, J.L., 1987. Chemistry of hydrothermal solutions from the southern Juan de Fuca Ridge. J. Geophys. Res., 92:1133411346.

Date of initial receipt: 16 August 1994

Date of acceptance: 28 February 1995

Ms 148SR-134 

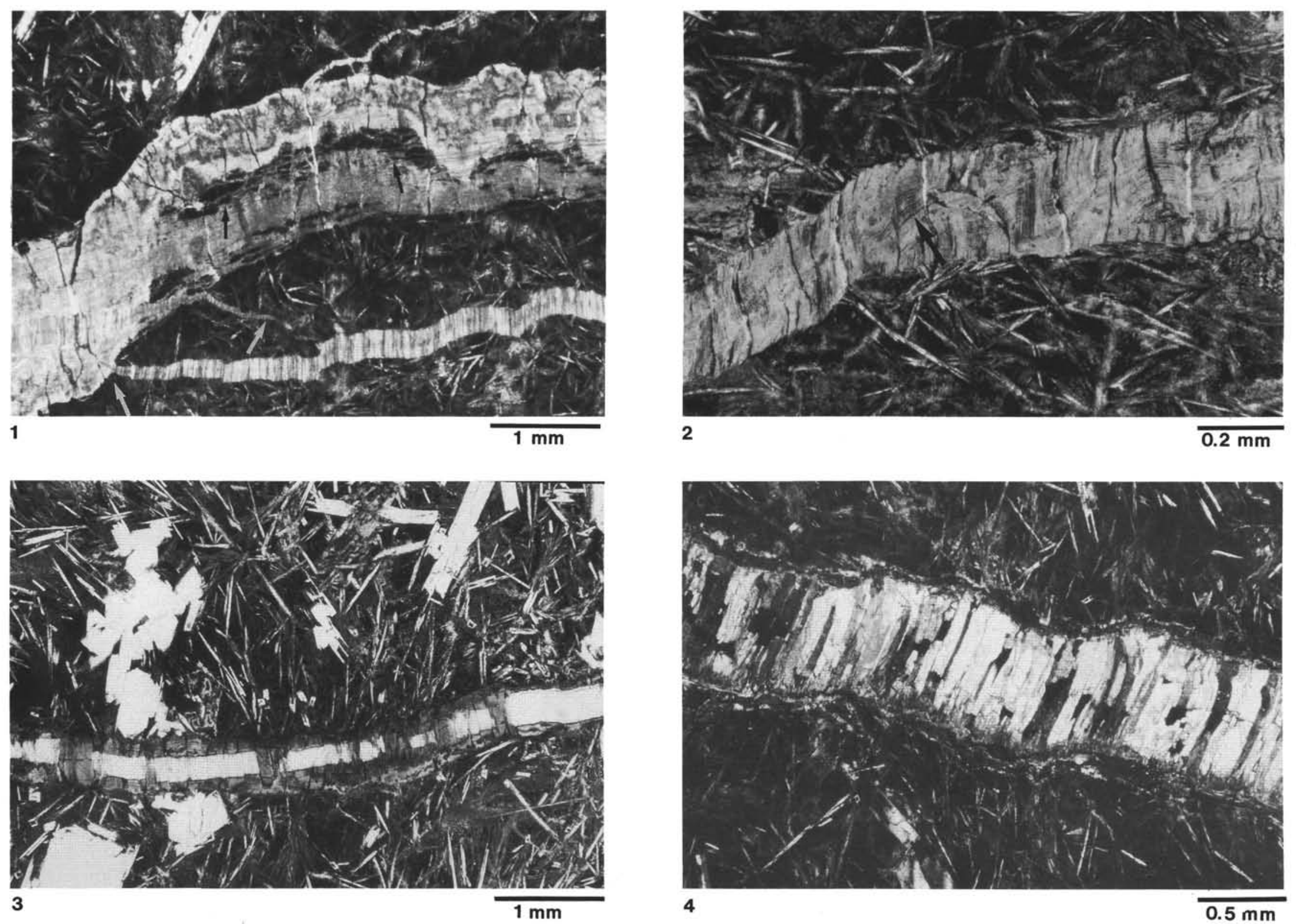

Plate 1. Photomicrographs of fibrous veins in basalts from Hole 896A. 1. Millimeter-scale smectite vein including fragments of the rock matrix (black arrows) that are arranged in bands subparallel to the vein walls. The vein is intersected by thinner veins filled with straight smectite fibers and showing overlapping hook-shaped (white arrows) vein segments (Sample 148-896A-26R-2, Piece 12). Plane light. 2. Hairline-like solid inclusion bands (black arrow) subparallel to vein walls in smectite fibers (Sample 148-896A-15R-1, Piece 7). Plane light. 3. Fibrous vein filled with smectite (gray) and carbonate (white) straight fibers (Sample 148-896A-6R-1, Piece 4). Hairline-like inclusion bands are present within smectite fibers. Plane light. 4. Fibrous vein filled with smectite fibers (on the vein walls) and carbonate straight or 

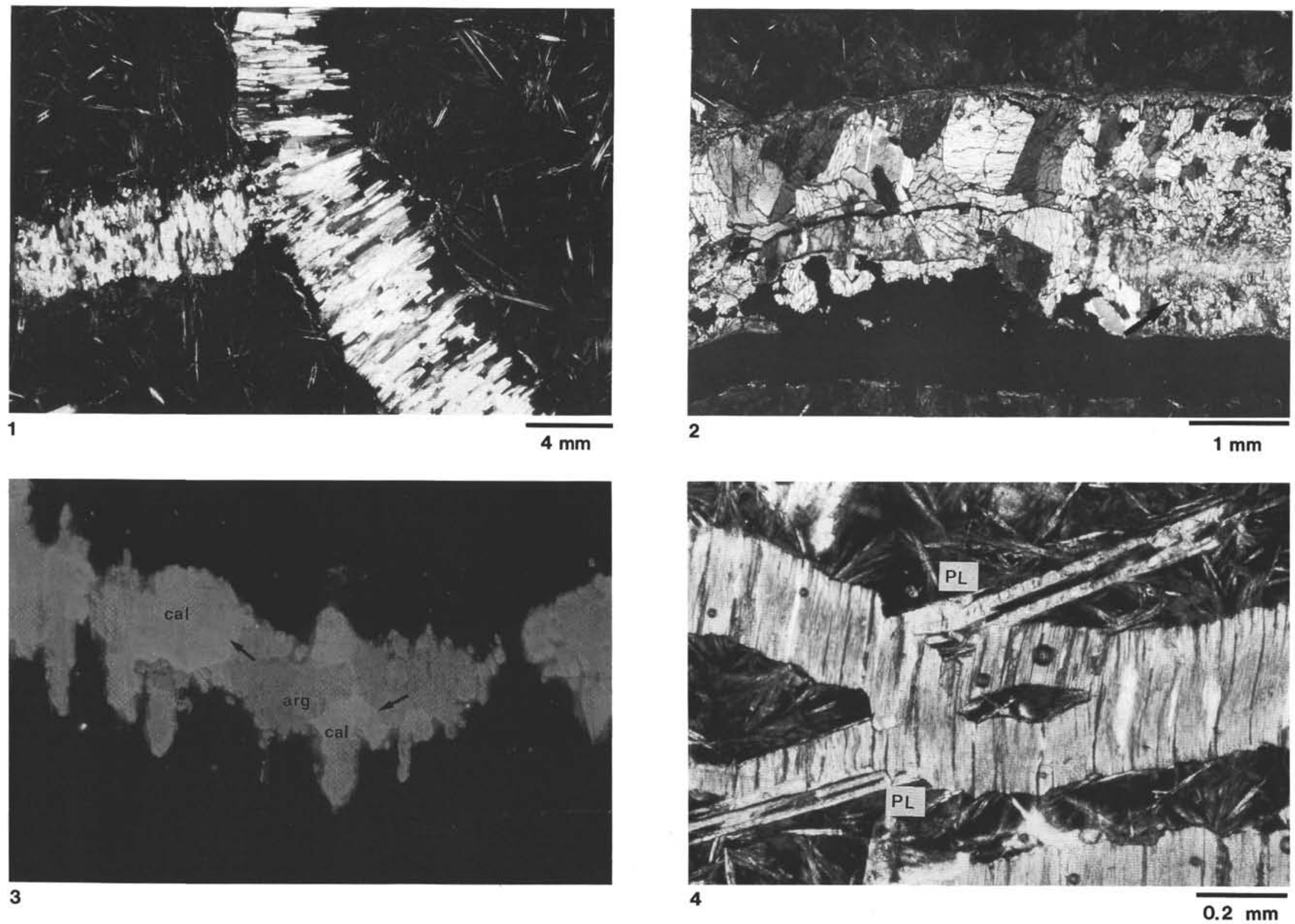

Plate 2. Photomicrographs of fibrous and composite veins. 1. Straight carbonate fibers filling veins forming a triple junction (Sample 148-896A-7R-1, Piece 22). Crossed nicols. 2. Composite vein filled with fibrous smectite (on the vein walls) and blocky carbonate crystals. Relict carbonate fibers are visible in the lower hand-right corner (black arrow) (Sample 148-896A-2R-1, Piece 17). Crossed nicols. 3. Optical cathodoluminescence micrograph of fibrous vein. Light gray ("cal" and arrows): second-generation carbonate (calcite) replacing first-generation carbonate fibers (dark gray, "arg"). Black: host rock. (Sample 148-896A-21R-1, Piece 7). 4. Fibrous smectite vein cutting a skeletal plagioclase lath (PL). Dilation may be inferred from mismatched points of the plagioclase lath on opposite vein walls. (Sample 148-896A26R-2, Piece 12). Plane light. 